\title{
Peningkatan Hasil Belajar Siswa SMAN 2 Palembang melalui Model Discovery Learning pada Materi Trigonometri
}

\author{
Dinna Cilvia Asri ${ }^{1}$, Sangkot Samosir ${ }^{2}$ \\ ${ }^{1}$ MTs Negeri 1 Banyuasin, ${ }^{2}$ SMA Negeri 2 Palembang \\ 1dinnacasri@gmail.com, ${ }^{2}$ sangkotsamosir123@gmail.com
}

\begin{tabular}{l}
\hline \hline Article Info \\
\hline Article history: \\
Received April $17^{\text {th }}, 2020$ \\
Revised May $22^{\text {th }}, 2020$ \\
Accepted May $22^{\text {th }}, 2020$ \\
\hline
\end{tabular}

Keywords:

Discovery Learning;

Learning Outcomes;

Mathematics

\begin{abstract}
The research conducted was classroom action research to improve the learning outcomes of students of class XI MIPA 6 Senior High School 2 Palembang. Improved learning outcomes are carried out by using the discovery learning model during the learning process. As for this research, using a subject consisting of 35 students. The subject used by researchers in this study is the formula of the sum and difference of sine, cosine, and tangent of two angles. In the first cycle consisted of 3 meetings and Cycle II consisted of 2 meetings. This study uses instruments in the form of test results of learning and observation. Tests of learning outcomes are used by researchers as a way to find out the achievements of students from each cycle and observations are used by researchers to collect data during the learning process takes place. Quantitative and descriptive data analysis was used in this study. Based on the results of the study, it was found that the average value of students of class XI MIPA 6 on the first cycle test was 63.00 and increased on the second cycle test to 83.69. The results of this study indicate that learning using the discovery learning model can improve students' mathematics learning outcomes, i.e. $74.28 \%$ of students have achieved indicators of success in the second cycle of research.
\end{abstract}

\author{
Kata Kunci: \\ Discovery Learning; \\ Hasil Belajar; \\ Matematika
}

\begin{tabular}{l} 
Abstrak \\
Penelitian tindakan kelas ini bertujuan untuk \\
meningkatkan hasil belajar siswa kelas XI MIPA 6 SMA \\
Negeri 2 Palembang. Peningkatan hasil belajar dilakukan \\
dengan adanya penggunaan model discovery learning \\
selama berlangsungnya proses pembelajaran. Adapun \\
subjek terdiri dari 35 orang siswa. Pokok bahasan pada \\
penelitian ini adalah rumus jumlah dan selisih sinus, \\
\hline
\end{tabular}


cosinus, dan tangen dua sudut. Pada siklus I terdiri dari 3 pertemuan dan Siklus II terdiri dari 2 pertemuan. Penelitian ini menggunakan instrumen berupa tes hasil belajar dan observasi. Tes hasil belajar digunakan sebagai cara untuk mengetahui capaian siswa dari masing-masing siklusnya dan observasi digunakan untuk mengumpulkan data aktivitas siswa dan guru selama proses pembelajaran berlangsung. Digunakan analisis data secara kuantitatif dan deskriptif pada penelitian ini. Hasil penelitian menunjukkan bahwa nilai rata-rata siswa kelas XI MIPA 6 pada tes siklus I adalah 63,00 dan meningkat pada tes siklus II menjadi 83,69. Oleh karena itu, dapat disimpulkan bahwa pembelajaran dengan menggunakan model discovery learning dapat meningkatkan hasil belajar matematika siswa, yaitu sebesar 74,28\% siswa telah mencapai indikator keberhasilan pada siklus II penelitian.

\section{PENDAHULUAN}

Salah satu pelajaran yang sangat penting untuk dipelajari oleh siswa pada setiap jenjang pendidikan adalah matematika. Hal ini seperti yang tercantum dalam Permendikbud Nomor 58 Tahun 2014 bahwa matematika sebagai ilmu yang universal memiliki peran penting dalam berbagai disiplin dan memajukan daya pikir manusia. Oleh karena itu, keberhasilan siswa dalam belajar matematika merupakan hal yang sangat diharapkan dalam dunia pendidikan.

Ketercapaian tujuan pembelajaran matematika ditentukan berdasarkan kriteria ketuntasan minimal (KKM). Untuk kelas XI SMA Negeri 2 Palembang pada tahun pelajaran 2018/2019 KKM yang digunakan adalah 73. Namun, fakta di lapangan menunjukkan bahwa lebih dari 78\% siswa kelas XI SMA Negeri 2 Palembang memiliki nilai kurang dari KKM untuk pokok bahasan trigonometri.

Trigonometri adalah salah satu materi yang sulit dipahami oleh siswa. Hal ini dikarenakan materi trigonometri yang memiliki banyak rumus dan jauh dari kehidupan sehari-hari siswa. Menurut Yulandari (2012) siswa mengalami kebingungan dalam menerapkan materi trigonometri sehingga materi ini dianggap sulit oleh siswa. Hasil 
wawancara dengan siswa mengungkapkan bahwa pembelajaran yang telah dilakukan sebelumnya hanya terbatas pada metode konvensional yang membuat siswa semakin sulit untuk bisa mengerti maksud dari materi trigonometri. Hal ini tentu semakin membuat rendahnya hasil belajar matematika, khususnya pokok bahasan trigonometri.

Sebagai upaya untuk mengatasi masalah tersebut, dibutuhkan suatu model pembelajaran yang menarik dan merangsang siswa untuk ikut aktif mengonstruksi pelajaran. Pembelajaran yang berpusat terhadap siswa dapat meningkatkan hasil belajar matematika siswa. Hal ini seperti yang disampaikan oleh Bruner et al. (2005) bahwa cara belajar yang baik adalah dengan cara memahami konsep, arti, dan hubungan melalui suatu proses yang berakhir pada suatu kesimpulan (discovery learning). Penerapan discovery learning membantu siswa menemukan sendiri pemahamannya sehingga pengetahuan yang didapat akan lebih diingat dan meningkatkan hasil belajar siswa (Kementerian Pendidikan dan Kebudayaan Republik Indonesia, 2013).

Berdasarkan latar belakang tersebut, akan dilakukan penelitian yang menerapkan model discovery learning untuk meningkatkan hasil belajar matematika siswa kelas XI MIPA-6 SMA Negeri 2 Palembang. Penelitian ini berfokus pada materi trigonometri yang dipelajari pada semester ganjil tahun ajaran 2018/2019. Trigonometri sangat cocok dipelajari menggunakan model discovery learning karena menuntut siswa untuk menemukan rumus dan mengkonstruksi sendiri materi pelajarannya sehingga lebih mudah untuk dipahami.

Penggunaan model discovery learning dalam pembelajaran matematika siswa telah dibahas pada beberapa penelitian terdahulu. Mawaddah \& Maryanti (2016) mengungkapkan bahwa siswa yang belajar dengan model discovery learning memiliki pemahaman yang baik. Selain itu, penelitian oleh Ahmad (2016) pada materi trigonometri kelas X menggunakan model discovery learning juga terbukti mampu meningkatkan kemampuan penalaran matematika siswa. Hal ini juga sejalan dengan penelitian Tukaryanto et al. (2018) yang mengungkapkan bahwa kemampuan penalaran dan sikap percaya diri siswa dapat 
ditingkatkan dengan menerapkan model discovery learning pada pembelajaran matematika.

Berdasarkan uraian di atas, inovasi dalam pembelajaran matematika terutama pada materi trigonometri sangat diperlukan. Oleh karena itu, perlu dilakukan penelitian tindakan kelas yang berjudul "Peningkatan Hasil Belajar Siswa melalui Model Discovery Learning pada Materi Trigonometri di Kelas XI MIPA 6 SMA Negeri 2 Palembang”.

\section{METODE PENELITIAN}

Penelitian ini adalah Penelitian Tindakan Kelas (PTK). Penelitian dilakukan oleh pihak luar yang bukan merupakan guru tetapi memiliki keinginan untuk memecahkan permasalahan pada proses pembelajaran. Menurut Arikunto (2006) penelitian kolaboratif inisiatif digunakan oleh pihak luar yang memiliki keinginan untuk memecahkan masalah pada proses pembelajaran. Oleh karena itu, pada PTK ini termasuk jenis penelitian kolaboratif.

Pelaksanaan penelitian dilakukan sebanyak 2 (dua) siklus dengan menggunakan kompetensi dasar yaitu membedakan penggunaan rumus jumlah dan selisih sinus dan cosinus dan menyelesaikan masalah yang berkaitan dengan rumus jumlah dan selisih sinus dan cosinus. Adapun desain penelitian, yaitu 3 (tiga) pertemuan pada siklus I dan 2 (dua) pertemuan pada siklus II. Pada setiap siklus penelitian terdiri dari perencanaan, pelaksanaan, pengamatan, dan refleksi seperti tertera pada Gambar 1.
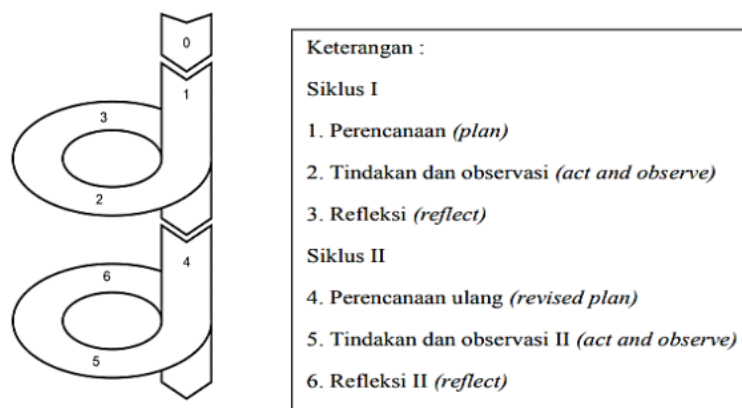

Gambar 1. Desain Penelitian 
Tahap pertama adalah perencanaan. Pada tahap ini terjadi aktivitas untuk mengembangkan rencana tindakan yang meliputi: (1) menentukan kompetensi dasar dan indikator untuk penelitian; (2) mendesain Rencana Pelaksanaan Pembelajaran (RPP) berdasarkan indikator yang telah ditentukan; (3) membuat bahan ajar yang digunakan pada penelitian; (4)membuat lembar aktivitas siswa untuk menunjang aktivitas siswa; (5)membuat butir-butir soal evaluasi yang digunakan pada penelitian; (6)membuat format penilaian yang akan digunakan pada penelitian; (7)menentukan tahapan model discovery learning; dan (8)melakukan tahapan diskusi dengan beberapa guru matematika tentang pelaksanaan pembelajaran.

Tahap kedua yaitu pelaksanaan. Pada tahap ini diimplementasikan proses pembelajaran sesuai dengan RPP. Pelaksanaan proses pembelajaran yang dilaksanakan menggunakan model Discovery learning. Penelitian ini dirancang sebanyak 2 (dua) siklus dengan jadwal kegiatan seperti tertera pada Tabel 1 .

Tabel 1. Jadwal Kegiatan Pembelajaran

\begin{tabular}{ccc}
\hline Siklus Ke & Pertemuan Ke & Tanggal \\
\hline \multirow{3}{*}{ Siklus I } & 1 & $5-09-2018$ \\
& 2 & $6-09-2018$ \\
& 3 & $12-09-2018$ \\
Siklus II & Tes 1 & $13-09-2018$ \\
\hline & 1 & $19-09-2018$ \\
& 2 & $20-09-2018$ \\
\hline
\end{tabular}

Tahap selanjutnya yaitu pengamatan. Pada tahap ini penelitian dilakukan dengan meminta bantuan rekan peneliti matematika sebanyak 2 (dua) orang. Adapun maksud dan tujuannya adalah sebagai pengamat selama proses pembelajaran berlangsung. Proses observasi difokuskan 
pada saat siswa melaksanakan setiap tahapan penggunaan model discovery learning.

Terakhir adalah tahap refleksi, pada tahap ini dilakukan evaluasi berdasarkan proses pembelajaran yang telah dilaksanakan pada siklus I untuk dijadikan bahan refleksinya nantinya pada pelaksanaan penelitian di siklus II. Refleksi dilakukan berdasarkan hasil pengamatan peneliti dan observer selama proses penelitian. Peneliti dan observer juga melakukan pembahasan hasil penilaian terhadap pelaksanaan pembelajaran yang dilakukan pada siklus untuk diajukan acuan pada siklus II berdasarkan standar keberhasilan yang telah ditetapkan pada tahapan sebelumnya.

Adapun teknik pengumpulan data yang digunakan adalah tes objektif dan observasi. Untuk mengukur aspek kognitif atau tingkat penguasaan materi pembelajaran digunakan tes objektif. Selanjutnya, observasi digunakan untuk mengamati aktivitas siswa dan guru selama proses pembelajaran.

Indikator keberhasilan pada penelitian ini, yaitu minimal $70 \%$ dari seluruh siswa memperoleh nilai paling kecil 73 . Nilai tersebut diperoleh dari hasil pengerjaan soal evaluasi pada tes objektif. Selain itu juga, sebagai penunjang indikator keberhasilan pada penelitian ini juga digunakan data dari hasil observasi.

\section{HASIL PENELITIAN DAN PEMBAHASAN}

Penelitian Tindakan Kelas (PTK) ini dilakukan di SMA Negeri 2 Palembang dengan menerapkan model discovery learning. Penelitian dilakukan di kelas XI MIPA 6 SMA Negeri 2 Palembang Tahun Ajaran 2018/2019 dengan banyak siswa seluruhnya adalah 35 siswa dengan komposisi 13 laki-laki dan 22 perempuan. Waktu penelitian dilaksanakan pada bulan September 2018 pada mata pelajaran matematika peminatan. Materi yang digunakan pada penelitian ini adalah materi trigonometri.

Penelitian dilaksanakan sebanyak dua siklus. Siklus I belajar tentang menentukan rumus jumlah dan selisih sudut cosinus dan sinus. Siklus II mempelajari rumus jumlah dan selisih sudut tangen.

Proses pembelajaran dengan menerapkan model discovery learning dilakukan pada setiap pertemuan. Observasi dilaksanakan untuk 
mengetahui aktivitas siswa selama mengikuti pembelajaran dari guru. Selanjutnya, setelah pembelajaran siklus I dilakukan evaluasi. Berdasarkan hasil evaluasi tersebut dilakukan perbaikan rencana pembelajaran yang kemudian akan diterapkan pada siklus II. Setelah pelaksanaan siklus II, untuk mengetahui peningkatan hasil belajar matematika siswa dilakukan evaluasi terakhir.

Setelah dilaksanakan pembelajaran pada siklus I sebanyak 3 (tiga) pertemuan, dilaksanakan evaluasi 1. Hasil belajar siswa dinilai dengan pemberian soal essai sebanyak 5 (lima) nomor. Pada Tabel 2 disajikan persentase hasil belajar dan ketuntasan siswa pada siklus I.

Tabel 2. Hasil Tes Siklus I

\begin{tabular}{ccccc}
\hline Nilai & Persentase & Kategori & Tuntas & Tidak Tuntas \\
\hline $80-89$ & $6 \%$ & Sangat Baik & 2 & 0 \\
\hline $70-79$ & $17 \%$ & Baik & 5 & 1 \\
\hline $60-69$ & $40 \%$ & Cukup & 0 & 14 \\
\hline $50-59$ & $17 \%$ & Kurang & 0 & 6 \\
\hline $40-49$ & $20 \%$ & Sangat Kurang & 0 & 7 \\
\hline \multicolumn{5}{c}{ Persentase Ketuntasan } \\
\hline
\end{tabular}

Berdasarkan Tabel 2., dapat dilihat bahwa hanya sebanyak $6 \%$ siswa yang mampu mencapai nilai pada kategori sangat baik dan $17 \%$ siswa mencapai kategori baik. Kemudian, siswa yang mampu mencapai Kriteria Ketuntasan Minimum (KKM) hanya sebanyak 7 orang atau 20\% dari keseluruhan siswa kelas XI MIPA 6. Hal ini didukung pula oleh ratarata nilai ulangan pada siklus I adalah 63,00. Rata-rata nilai ini masih termasuk di bawah KKM pada mata pelajaran matematika peminatan.

Selanjutnya, pada pembelajaran siklus I didapatkan hasil observasi sebagai berikut: (1) siswa belum terbiasa menggunakan Lembar Kerja Peserta Didik (LKPD) pada proses pembelajaran; (2) siswa masih terlalu membutuhkan bantuan guru pada proses menentukan rumus yang diminta pada LKPD; (3) masing-masing siswa belum aktif secara penuh untuk 
saling berdiskusi dalam menentukan rumus yang diminta pada LKPD; (4) masih ditemukan keraguan pada setiap kelompok dalam menulis penyelesaian LKPD meskipun setiap kelompok sudah memiliki jawaban yang sudah benar; (5) bimbingan dari guru belum maksimal karena ada kelompok yang tidak terjamah oleh guru. Hal ini disebabkan guru terlalu lama berada di salah satu kelompok sehingga mengabaikan yang lain; dan (6) prosedur pengerjaan LKPD yang dijelaskan oleh guru pada kegiatan pendahuluan kurang dapat dipahami dengan baik oleh siswa sehingga membuat siswa menanyakan pertanyaan yang sama berulang-ulang terkait prosedur pengerjaan LKPD.

Hasil belajar matematika siswa pada siklus I belum memenuhi indikator keberhasilan penelitian jika dilihat dari hasil evaluasi dan catatan observasi. Maka, perlu dilakukan refleksi dan evaluasi pada pembelajaran yang sudah terlaksana. Selanjutnya, rencana pembelajaran diperbaiki berdasarkan hasil refleksi dan evaluasi tersebut. Setelah proses perbaikan ini, diharapkan pembelajaran pada siklus II dapat terlaksana dengan lebih baik dan lebih dipahami oleh siswa. Prosedur pengerjaan LKPD juga dibuat lebih rinci dan jelas agar siswa dapat bekerja secara mandiri dan tidak terus-menerus meminta arahan dari guru.

Setelah pembelajaran di siklus II selesai, guru melaksanakan evaluasi II untuk melihat capaian hasil belajar siswa. Adapun hasil belajar siswa dinilai menggunakan soal evaluasi tipe objektif dan essai.

Tabel 3. Hasil Tes Siklus II

\begin{tabular}{ccccc}
\hline Nilai & Persentase & Kategori & Tuntas & Tidak Tuntas \\
\hline $80-89$ & $51,43 \%$ & Sangat Baik & 18 & 0 \\
\hline $70-79$ & $28,57 \%$ & Baik & 8 & 2 \\
\hline $60-69$ & $20 \%$ & Cukup & 0 & 7 \\
\hline $50-59$ & $0 \%$ & Kurang & 0 & 0 \\
\hline $40-49$ & $0 \%$ & Sangat Kurang & 0 & 0 \\
\hline \multicolumn{5}{c}{ Persentase Ketuntasan } \\
\hline
\end{tabular}


Tabel 3 tersebut menyajikan persentase hasil belajar dan ketuntasan siswa pada siklus II. Berdasarkan hasil pada tabel tersebut, dapat dilihat bahwa ada sebanyak 28,57\% siswa yang dapat memperoleh nilai pada rentang 70-79 dengan kategori baik dan sebanyak 51,43\% mampu memperoleh nilai di rentang 80-89 dengan kategori sangat baik. Kemudian, siswa yang mampu mencapai KKM ada sebanyak 26 orang atau $74,28 \%$ dari keseluruhan siswa kelas XI MIPA 6. Persentase ini menunjukkan bahwa kriteria keberhasilan penelitian telah tercapai. Hal ini didukung pula oleh rata-rata nilai ulangan pada siklus II, yaitu 83,69. Hal ini menunjukkan bahwa hasil belajar siswa sudah melebihi batas KKM untuk mata pelajaran Matematika Peminatan.

Adapun pada pembelajaran siklus II didapatkan hasil observasi sebagai berikut: (1) siswa sudah terbiasa menggunaan LKPD pada proses pembelajaran; (2) siswa sudah tidak lagi terlalu banyak membutuhkan bantuan guru pada proses menentukan rumus yang diminta pada LKPD; (3) masing-masing siswa sudah secara aktif penuh untuk saling berdiskusi dalam menentukan rumus yang diminta pada LKPD; (4) sudah jarang ditemukan keraguan pada setiap kelompok dalam tiap penulisan penyelesaian pada LKPD meskipun setiap kelompok sudah memiliki jawaban yang sudah benar; (5) bimbingan dari guru sudah cukup maksimal karena seluruh kelompok bisa mendapat bimbingan yang baik dari guru; dan (6) prosedur pengerjaan LKPD yang dijelaskan oleh guru pada kegiatan pendahuluan dapat dipahami dengan baik oleh siswa sehingga tidak membuat siswa menanyakan pertanyaan yang sama berulang-ulang.

Berdasarkan nilai evaluasi II dan hasil observasi pada siklus II, dapat disimpulkan bahwa hasil belajar siswa telah mencapai indikator keberhasilan penelitian. Oleh karena itu, penelitian tindakan kelas ini dianggap selesai dan tidak diperlukan siklus lanjutan.

Hasil evaluasi pada setiap siklus dan data hasil pengamatan menunjukkan bahwa terjadi peningkatan hasil belajar matematika siswa kelas XI MIPA 6. Penggunaan model discovery learning mampu menuntun siswa untuk dapat menemukan sendiri pemahamannya. Selain 
itu, dengan digunakannya model discovery learning, siswa terbiasa untuk dapat menyelesaikan tugasnya sendiri secara mandiri dengan tetap melibatkan diskusi bersama kelompok. Diskusi pada kelompok juga menjadikan proses pembelajaran lebih aktif sehingga siswa lebih memiliki motivasi yang besar dalam mengikuti setiap rangkaian proses pembelajaran. Hal ini sejalan dengan hasil penelitian yang pernah dilakukan oleh Wahyudi \& Siswanti (2015), Fitriyah et al. (2017), dan Oktaviani et al. (2018) bahwa model discovery learning mampu meningkatkan hasil belajar matematika siswa.

\section{SIMPULAN}

Berdasarkan hasil analisis dan pembahasan, dapat disimpulkan bahwa pembelajaran menggunakan model discovery learning dapat meningkatkan hasil belajar matematika siswa di Kelas XI MIPA 6 SMA Negeri 2 Palembang. Hal ini dapat dibuktikan dengan nilai evaluasi pada siklus II, yaitu sebanyak 26 orang atau 74,28\% dari keseluruhan siswa kelas XI MIPA 6 mencapai nilai di atas KKM dengan rata-rata nilai 83,69 . Selanjutnya, berdasarkan hasil observasi pada siklus II juga dapat dilihat bahwa aktivitas belajar siswa lebih baik daripada siklus I. Adapun pembelajaran yang dilakukan oleh guru juga semakin baik pada siklus II.

\section{DAFTAR PUSTAKA}

(Kementerian Pendidikan dan Kebudayaan Republik Indonesia). (2013).

Implementasi Kurikulum. Permendikbud. https://doi.org/10.1017/ CBO9781107415324.004

Ahmad, H. (2016). PENINGKATAN KEMAMPUAN PENALARAN MATEMATIKA MATERI TRIGONOMETRI MELALUI PENERAPAN MODEL PEMBELAJARAN DISCOVERY LEARNING DENGAN PENDEKATAN SAINTIFIK PADA KELAS X SMA NEGERI 11 MAKASSAR. Jurnal Daya Matematis. https://doi.org/10.26858/jds.v3i3.1697 Arikunto, S. (2006). Prosedur Penelitian Tindakan Kelas. Bumi Aksara Bruner, M. K., Hilgers, K. K., Silveira, A. M., \& Butters, J. M. (2005).

Graduate orthodontic education: The residents' perspective. 
American Journal of Orthodontics and Dentofacial Orthopedics. https://doi.org/10.1016/j.ajodo.2005.04.031

Fitriyah, F., Murtadlo, A., \& Warti, R. (2017). Pengaruh Model Pembelajaran Discovery Learning terhadap Hasil Belajar

Matematika Siswa MAN Model Kota Jambi. Jurnal Pelangi. https://doi.org/10.22202/jp.2017.v9i2.1898

Mawaddah, S., \& Maryanti, R. (2016). Kemampuan Pemahaman Konsep

Matematis Siswa SMP dalam Pembelajaran Menggunakan Model

Penemuan Terbimbing (Discovery Learning). EDU-MAT: Jurnal

Pendidikan Matematika. https://doi.org/10.20527/edumat.v4i1.2292

Oktaviani, W., Kristin, F., \& Anugraheni, I. (2018). PENERAPAN

MODEL PEMBELAJARAN DISCOVERY LEARNING UNTUK

MENINGKATKAN KEMAMPUAN BERPIKIR KRITIS DAN HASIL BELAJAR MATEMATIKA SISWA KELAS 5 SD. Jurnal

Basicedu. https://doi.org/10.31004/basicedu.v2i2.41

Tukaryanto, Hendikawati, P., \& Nugroho, S. (2018). Peningkatan

Kemampuan Penalaran Matematik dan Percaya Diri Siswa Kelas X

Melalui Model Discovery Learning. PRISMA, Prosiding Seminar

Nasional Matematika

Wahyudi, W., \& Siswanti, M. C. (2015). PENGARUH PENDEKATAN SAINTIFIK MELALUI MODEL DISCOVERY LEARNING DENGAN PERMAINAN TERHADAP HASIL BELAJAR MATEMATIKA SISWA KELAS 5 SD. Scholaria: Jurnal Pendidikan Dan Kebudayaan.

https://doi.org/10.24246/j.scholaria.2015.v5.i3.p23-36

Yulandari, T. I. (2012). Pengembangan Lembar Kerja Siswa Materi Trigonometri untuk Siswa SMA Kelas X dengan Metode Penemuan Terbimbing. Jurnal Online Universitas Negeri Malang, 1(2) 
46 | Asri dan Samosir: Peningkatan Hasil Belajar Siswa SMAN 2 Palembang melalui ... 